\title{
Acute Toxicity of Paraquat Dichloride on Fingerlings of Oreochromis niloticus
}

\author{
Ademola Michael Akinsorotan', Abimbola Funmilayo Ajisodun ${ }^{1}$, Sylvester Chibueze Izah ${ }^{2}$, \\ Jeremiah Olanipekun Jimoh ${ }^{1}$ \\ ${ }^{I}$ Department of Fisheries and Aquaculture, Federal University Oye-Ekiti, Ekiti State, Nigeria \\ ${ }^{2}$ Department of Biological Sciences, Niger Delta University, Wilberforce Island, Bayelsa State, Nigeria
}

*Corresponding Author: Ademola Michael Akinsorotan, Department of Fisheries and Aquaculture, Federal University Oye-Ekiti, Ekiti State, Nigeria

\begin{abstract}
The toxicity effect of paraquat dichloride on fingerlings of Oreochromis niloticus was investigated. The fishes were allowed to acclimatize in the laboratory for 2 week. Range finding test was carried prior to final test. At the definitive test the fishes were exposed to lethal concentrations of $0.00 \mathrm{mg} / \mathrm{L}, 27.60 \mathrm{mg} / \mathrm{L}$, $33.12 \mathrm{mg} / \mathrm{L}, 38.64 \mathrm{mg} / \mathrm{L}, 44.16 \mathrm{mg} / \mathrm{L}$ and $49.64 \mathrm{mg} / \mathrm{L}$ of paraquat dichloride for 96 hours following renewal bioassay. The toxicity bioassay showed that the 96 hours $L C_{50}$ was $40.768 \mathrm{mg} / \mathrm{l}$. Behavioral responses which include restlessness, erratic swimming, loss of equilibrium, discolouration, and sudden fish death were observed in the exposed fish and these varied greatly with differences in concentrations of the toxicant. Mortality increases with increase in concentration. The differences observed in the mortalities of Oreochromis niloticus at varying concentrations were significant $(p<0.05)$, an indication that mortality could be a factor of concentration and time of exposure. The physico-chemical parameters of the water used for the experiment were within the tolerated limit. Based on the findings of this study there is the need to control the use of paraquat based herbicides close to aquatic ecosystems.
\end{abstract}

Keywords: Aquatic pollution, Fishes, Paraquat dichloride, Toxicity

\section{INTRODUCTION}

In recent times, population growth, industrialization, urbanization, extensive agricultural practices leading to deforestation and use of agrochemicals appears to be contributing to anthropogenic activities that could impacts on the environmental sustainability. Human activities due to deforestation have led to soil erosion in many regions of the world especially in developing nations. Most soil pollutant end up in nearby surface water including rivers, streams, creeks, creeklets, ponds, etc. Studies have suggested that water quality is rapidly declining due to human activities in the ecosystem especially in developing nations (Aghoghovwia et al., 2018a-c, Izah et al., 2016; Izah and Srivastav, 2015; Agedah et al., 2015; Ben-Eledo et al., 2017a,b; Seiyaboh and Izah, 2017a,b; Seiyaboh et al., 2017; Ogamba et al., 2015a-c).

Pesticides are used to control pests. Their roles depend on the target organisms. For instances, pesticides that are used in controlling weeds, ticks, insects and rodents are knows as herbicides, acaricides, insecticides and rodenticides respectively. In modern day agriculture the use of herbicides in agricultural fields, urban setting have increased (Aghoghovwia and Izah, 2018a,b). Most herbicides have the tendency to endanger non target organisms at certain concentration. This typically occurs when the herbicides end up in the aquatic ecosystem due to runoff after rainfall (soil erosion) (Inyang et al., 2016a-f, 2017a-d, 2018; Ojesanmi et al., 2017; Ogamba et al., 2015d).

The increasing use of herbicides and pesticides in agriculture (including commercial and household production of vegetables) for the control of pest and herb causes chemical pollution of aquatic environment. The chemical pollution causes potential health hazards to live stock, especially to arthropods, fish, frogs, birds and even mammals. The toxicity level depends on route of exposure, concentrations, age of the organisms. 
Paraquat is a common brand of non-selective herbicides used for the control of several broad leaved and grasses in plantations and other weeds in non-crop land/ urban and household settings worldwide (Aghoghovwia and Izah, 2018a). The authors further reported that paraquat dichloride acts as a defoliant for some plants. Basically paraquat is a quaternary nitrogen based herbicides that destroy plant tissues. Furthermore, paraquat acts on the tissue of several plant through contact processes (Banaee et al., 2013; Aghoghovwia and Izah, 2018a).

The toxicity of paraquat based herbicides on human health is based on inhalation, ingestion and damaged skin integrity (Arivu et al., 2016). The exposure due via damaged skin tissues could be associated to the corrosive nature (Aghoghovwia and Izah, 2018a). Toxicity of Paraquat through the use of leaking knapsack sprayer has been documented by Arivu et al. (2016). Despite the fact the manufactirers have considered it safe for use, Ariyu et al. (2016) have reported that its toxic to human health because of its tendency to cause multi-organ failure (viz: lungs, heart, kidneys, adrenal glands, central nervous system, liver, muscles and spleen) and induce respiratory disorder.

Toxic substances in aquatic environment can affect fish growth indirectly by reducing food availability, or directly by changing their metabolism processes (Nwaniet al., 2014). Generally most herbicides have the tendency to hamper reproduction, food conversion efficiency, growth and mortality among aquatic organisms. Fish are among the organisms used in ecotoxicological studies probably due to their sensitive to the aquatic pollutants. To this effect cat fish especially Clarias gariepinus (Ladipo, 2011), and Heterobranchus bidorsalis (Aghoghovwia and Izah, 2018a) are the most common group of fish use in toxicological studies in Nigeria. Tilapia, Oreochromis niloticus which belong to the family Cichlidae is a freshwater surface feeding omnivore fish. The fish has fast growth rate. Oreochromis niloticus is basically a freshwater fish some can adapt to brackish and/ or marine water. Hence, this study aimed at determining the toxicity of paraquat based herbicides on the fingerlings of Oreochromis niloticus.

\section{Materials AND MethodS}

\subsection{Source of the Experimental Fish and Acclimatization}

The experimental fish, Oreochromis niloticus fingerlings were purchased at a fish farm in Ikole, Ekiti state and transported to laboratory with an open keg to the wet laboratory of Fisheries and Aquaculture Department, Federal University Oye-Ekiti, Ekiti State were the experiment was conducted. The average weight and length of the fish was $7.50 \mathrm{~g}$ and $5.66 \mathrm{~cm}$ respectively. The fingerlings were acclimatize in a 25 litres rectangular plastic tank for 2 weeks and feed on a pelleted feed. The water were changed daily during acclimatization and fed twice daily.

\subsection{Experiment Design}

A total of 216 Oreochromis niloticus fingerlings used were divided into six treatment (including 1 control and 5 different concentration of the toxicant) with three replicates. 12 fingerlings were stocked into each tank with replicate treatment. A range finding test (trial test) was carried out using the paraquat as a toxicant. Six concentrations of the paraquat were prepared from the original $(276 \mathrm{~g} / \mathrm{l})$.

\subsection{Experimental Protocol}

The range finding test previously described by Akinsorotan (2015) adopted in this study. The range finding test was necessary to determine the $\mathrm{LC}_{50}$ value of the test chemical on the fish. This was carried out with the permission of the animal ethic committee of Federal University, Oye Ekiti. Ekiti State, Nigeria. Prior to the definitive test, the fish were starved for 24 hours. This was necessary to reduce water pollution as a result of decomposition of fecal droppings. It was also necessary to reduce external stress to the fish that could arise from feeding. The definitive concentration of $0.00 \mathrm{mg} / \mathrm{l}$, $1.5 \mathrm{ml}, 1.8 \mathrm{ml}, 2.1 \mathrm{ml}, 2.4 \mathrm{ml}$, and $2.7 \mathrm{ml}$ were converted into $0.00 \mathrm{mg} / \mathrm{L}, 27.60 \mathrm{mg} / \mathrm{L}, \quad 33.12 \mathrm{mg} / \mathrm{L}$, $38.64 \mathrm{mg} / \mathrm{L}, 44.16 \mathrm{mg} / \mathrm{L}$ and $49.64 \mathrm{mg} / \mathrm{L}$ respectively and were measured with pipette from paraquat dichloride solution of $276 \mathrm{~g} / \mathrm{l}$ and were introduced into experimental tank of 15 litres of water in each tank. The definite test was carried in triplicate.All procedures were in accordance with the ethical standard of the animal ethic committee of Federal University, Oye Ekiti, Ekiti State, Nigeria. 


\subsection{Behavioral Response}

The behavioral and morphological response of the fish is observed after exposure of the fish to various concentration of the toxicant. The control tank was monitored with the tanks of various concentration of the toxicant, assessing any behavioral or morphological changes. The responses which are air gulping index, opercular ventilation count, tail fin movement, restlessness, erratic swimming, barbell deformation, loss of reflex were recorded from $24 \mathrm{hrs}-96 \mathrm{hrs}$. The air gulping index, opercula ventilation count and tail fin movement rate was carried out for 96 hours which were counted using stop watch at 12, 24, 48, 72 and 96 hours per minutes (Okechukwu et al., 2013). Two fish were used for the counting per tank and values were computed.

\subsection{Mortality Rates}

Mortality was also recorded from 24 - 96hrs.Mortality was confirmed when the fishes did not respond to repeated prodding (Oyoroko and Ogamba, 2017a). Mortality rate of the fish samples were calculated as:

Mortality rate $=\frac{\text { Number of dead fish }}{\text { Total number of fish exposed to the toxicant }} \times 100$

\subsection{Water Quality Analysis}

The water quality parameters viz: temperature, dissolved oxygen, conductivity $\mathrm{pH}$ were determined using water analysis kit (Model SX751pH ORP/Conductivity/DO). Each of the parameters analyzed was calibrated with the corresponding fluids prior to analysis.

\subsection{Statistical Analysis}

Probit analysis (Finney, 1971) was used to determine $\mathrm{LC}_{50}$. Data was subjected to one-way analysis of variance (ANOVA) using SPSS software version 16.0 to test for the significant differences between means . Graph analysis were plotted using Microsoft excel window 2010.

\section{RESULTS AND DISCUSSION}

Temperature and dissolved oxygen ranged from $22.53-24.13^{\circ} \mathrm{C}$ and $5.38-5.68 \mathrm{mg} / \mathrm{l}$ respectively across all the exposure period. The $\mathrm{pH}$ was within the range recommended for water mean for aquaculture ranging from $6.53-7.10$ for all the exposure period. $\mathrm{pH}$ typically has the tendency to cause an alteration biochemical activities of the aquarium water probably during oxidation and reduction processes. The conductivity range from $53.53-188.40 \mu \mathrm{S} / \mathrm{cm}$ for all exposure duration and concentration (Table 1). At exposure of the toxicant for 96hours, there was an increase in $\mathrm{pH}$ and conductivity, and decrease in dissolved oxygen. The fluctuations that occur between the various concentration and time could be due to the fact that these parameters are highly unstable. The water quality parameters under study are within the standard meant for aquaculture purposes. For instances, authors have reported $\mathrm{pH}$ of 6.5 - 9.0 to support fish life (Boyd, 1979; Okomoda and Ataguba, 2011; Oloruntuyi et al., 1993). Bhatnagar and Devi (2013) also reported that catfishes and other air breathing fishes can tolerate low Dissolved oxygen concentration of $4 \mathrm{mg} / \mathrm{l}$. Hence the dissolve oxygen content is within the values necessary for fish life. Basically in aquatic ecosystem temperature is very essential for the survival of fishes through metabolism. As such inability of fish to adapt to the environment could cause a change in their physiological response which could lead to mortality. The temperature is within the ambient temperature of the area and values of surface water resources in Nigeria (Agedah et al., 2015; Ben-Eledo et al., 2017a). Hence the fishes may not have died due to temperature.

Table1. Water quality parameters of paraquat dichloride herbicide on fingerlings of Oreochromis niloticus

\begin{tabular}{|l|l|l|l|l|l|l|l|}
\hline $\begin{array}{l}\text { Exposure } \\
\text { period }\end{array}$ & Parameter & $0.00, \mathrm{mg} / \mathrm{l}$ & $2.76, \mathrm{mg} / \mathrm{l}$ & $3.31, \mathrm{mg} / \mathrm{l}$ & $3.86, \mathrm{mg} / \mathrm{l}$ & $4.42, \mathrm{mg} / \mathrm{l}$ & $4.97, \mathrm{mg} / \mathrm{l}$ \\
\hline $24 \mathrm{hrs}$ & $\begin{array}{l}\text { Temperature, } \\
{ }^{\circ} \mathrm{C}\end{array}$ & $24.13 \pm 0.11$ & $24.03 \pm 0.29$ & $24.07 \pm 0.06$ & $23.93 \pm 0.06$ & $23.97 \pm 0.06$ & $23.76 \pm 0.1$ \\
\cline { 2 - 8 } & $\mathrm{DO}, \mathrm{mg} / \mathrm{l}$ & $5.38 \pm 0.02$ & $5.39 \pm 0.03$ & $5.40 \pm 0.01$ & $5.40 \pm 0.01$ & $5.39 \pm 0.03$ & $5.46 \pm 0.02$ \\
\cline { 2 - 8 } & $\mathrm{pH}$ & $6.53 \pm 0.06$ & $6.57 \pm 0.06$ & $6.53 \pm 0.12$ & $6.53 \pm 0.06$ & $6.47 \pm 0.06$ & $6.53 \pm 0.15$ \\
\cline { 2 - 8 } & $\begin{array}{l}\text { Conductivity, } \\
\mu \mathrm{S} / \mathrm{cm}\end{array}$ & $53.53 \pm 2.89$ & $75.32 \pm 1.14$ & $139.60 \pm 16.39$ & $132.50 \pm 4.30$ & $139.83 \pm 11.85$ & $137.43 \pm 19$ \\
\hline
\end{tabular}




\begin{tabular}{|c|c|c|c|c|c|c|c|}
\hline \multirow[t]{4}{*}{$48 \mathrm{hrs}$} & $\begin{array}{l}\text { Temperature, } \\
{ }^{\circ} \mathrm{C}\end{array}$ & $23.53 \pm 0.06$ & $23.20 \pm 0.17$ & $23.40 \pm 0.10$ & $23.60 \pm 0.1$ & $23.50 \pm 0.10$ & $23.3 \pm 0.10$ \\
\hline & $\mathrm{DO}, \mathrm{mg} / \mathrm{l}$ & $5.52 \pm 0.02$ & $5.55 \pm 0.01$ & $5.54 \pm 0.01$ & $5.50 \pm 0.03$ & $5.35 \pm 0.30$ & $5.55 \pm 0.01$ \\
\hline & $\mathrm{pH}$ & $6.70 \pm 0.10$ & $6.73 \pm 0.06$ & $6.87 \pm 0.06$ & $6.77 \pm 0.06$ & $6.87 \pm 0.06$ & $6.87 \pm 0.06$ \\
\hline & $\begin{array}{l}\text { Conductivity, } \\
\mu \mathrm{S} / \mathrm{cm}\end{array}$ & $95.07 \pm 5.66$ & $128.33 \pm 3.7$ & $188.40 \pm 23.98$ & $134.17 \pm 3.93$ & $149.43 \pm 16.07$ & $\begin{array}{l}173.34 \\
\pm 23.7\end{array}$ \\
\hline \multirow[t]{4}{*}{$72 \mathrm{hrs}$} & $\begin{array}{l}\text { Temperature, } \\
{ }^{\circ} \mathrm{C}\end{array}$ & $22.87 \pm 0.06$ & $22.77 \pm 0.23$ & $22.70 \pm 0.10$ & $22.80 \pm 0.44$ & $22.77 \pm 0.29$ & $22.67 \pm 0.1$ \\
\hline & DO & $5.59 \pm 0.06$ & $5.59 \pm 0.00$ & $5.60 \pm 0.06$ & $5.58 \pm 0.02$ & $5.62 \pm 0.00$ & $5.61 \pm 0.01$ \\
\hline & $\mathrm{pH}$ & $7.10 \pm 0.10$ & $7.07 \pm 0.06$ & $7.00 \pm 0.06$ & $7.10 \pm 0.06$ & $7.03 \pm 0.01$ & $6.93 \pm 0.0$ \\
\hline & $\begin{array}{l}\text { Conductivity, } \\
\mu \mathrm{S} / \mathrm{cm}\end{array}$ & $75.83 \pm 3.94$ & $82.43 \pm 2.05$ & $159.53 \pm 21.00$ & $153.23 \pm 11.6$ & $160.73 \pm 19.6$ & $177.6 \pm 20.88$ \\
\hline \multirow[t]{4}{*}{ 96hrs } & $\begin{array}{l}\text { Temperature, } \\
{ }^{\circ} \mathrm{C}\end{array}$ & $22.73 \pm 0.32$ & $22.60 \pm 0.10$ & $22.57 \pm 0.07$ & $22.47 \pm 0.16$ & $22.53 \pm 0.06$ & $22.56 \pm 0.11$ \\
\hline & $\mathrm{DO}, \mathrm{mg} / \mathrm{l}$ & $5.61 \pm 0.03$ & $5.62 \pm 0.01$ & $5.63 \pm 0.06$ & $5.63 \pm 0.06$ & $5.62 \pm 0.01$ & $5.62 \pm 0.11$ \\
\hline & $\mathrm{pH}$ & $6.97 \pm 0.06$ & $7.03 \pm 0.12$ & $6.97 \pm 0.06$ & $6.97 \pm 0.06$ & $6.93 \pm 0.06$ & $6.80 \pm 0.1$ \\
\hline & $\begin{array}{l}\text { Conductivity, } \\
\mu \mathrm{S} / \mathrm{cm}\end{array}$ & $117.67 \pm 4.4$ & $102.80 \pm 32.5$ & $141.53 \pm 17.55$ & $89.50 \pm 11.26$ & $96.03 \pm 24.3$ & $112.70 \pm 19.0$ \\
\hline
\end{tabular}

Data were expressed as mean \pm standard deviation

Oreochromis niloticus showed behavioral changes on exposure to paraquat herbicide (Table $2-4$ ). Immediately the fish were introduced into the tank containing paraquat at concentrations $2.76 \mathrm{mg} / \mathrm{l}$, $3.31 \mathrm{mg} / \mathrm{l}, 3.86 \mathrm{mg} / \mathrm{l}, 4.42 \mathrm{mg} / \mathrm{l}$ and $4.97 \mathrm{mg} / \mathrm{l}$, they became restless and agitated. Fishes came to the surface of water much more frequently. They occasionally tried to jump out of the water. The fish showed abnormal swimming movements including loss of orientation, loss of buoyancy and spasms before death. Typically, acute toxicity of most fishes is characterized by excessive gulping of air and intermittent swarming, erratic swimming, restlessness, loss of movement, increased operculum movement, excessive secretion of mucus and body pigmentation, and jerky movement (Oyoroko and Ogamba, 2017b; Inyanget al., 2017a). Behavioural response could be affected by concentrations of toxicants, age, species and prevailing environmental condition (Omoniyi et al., 2002).

Air gulping were observed and counted per minute. The result of air gulping of the exposed fish to the toxicant increases especially during 24 hours and 48hours when compared to the control (Table 2). At $0.00 \mathrm{mg} / \mathrm{l}, 27.60 \mathrm{mg} / \mathrm{L}, 33.12 \mathrm{mg} / \mathrm{L}, 38.64 \mathrm{mg} / \mathrm{L}, 44.16 \mathrm{mg} / \mathrm{L}$ and $49.64 \mathrm{mg} / \mathrm{L}$ concentrations, the air gulping index were $19.33 \pm 0.33,59.33 \pm 0.58,49.67 \pm 8.14,48.00 \pm 5.57,50.00 \pm 6.08$ and $62.67 \pm 2.52$ respectively for 24 hours treatment; $26.00 \pm 0.00,83.67 \pm 7.57,76.00 \pm 3.00,67.52 \pm 2.08,88.00 \pm 4.58$ and $89.00 \pm 3.00$ respectively for 48 hours treatment and $27.00 \pm 5.29,82.67 \pm 0.00,81.33 \pm 6.81,80.00 \pm 6.08$, $98.5 \pm 6.66$ and $81.67 \pm 6.35$ respectively for 96 hours treatment. The air gulping index showed a significant increase $(\mathrm{p}<0.05)$ between 24 hours and other exposure duration except for $2.76 \mathrm{mg} / \mathrm{l}$ and $4.42 \mathrm{mg} / \mathrm{l}$ at 72 hours. The air gulping index showed respiratory distress probably due the effect of the toxicants.

Table2. Effect of acute concentration of paraquat with time on Oreochromis niloticus air gulping index movement

\begin{tabular}{|l|l|l|l|l|}
\hline \multicolumn{5}{|l|}{ Exposure duration } \\
\hline Conc $(\mathrm{mg} / \mathrm{l})$ & \multicolumn{1}{|l|}{$24 \mathrm{hrs}$} & \multicolumn{1}{l|}{$48 \mathrm{hrs}$} & $72 \mathrm{hrs}$ & $96 \mathrm{hrs}$ \\
\hline 0.00 & $19.33 \pm 0.33^{\mathrm{a}}$ & $26.00 \pm 0.00^{\mathrm{b}}$ & $25.00 \pm 1.00^{\mathrm{b}}$ & $27.00 \pm 5.29^{\mathrm{b}}$ \\
\hline 2.76 & $59.33 \pm 0.58^{\mathrm{a}}$ & $83.67 \pm 7.57^{\mathrm{b}}$ & $61.67 \pm 5.51^{\mathrm{a}}$ & $82.67 \pm 0.00^{\mathrm{b}}$ \\
\hline 3.31 & $49.67 \pm 8.14^{\mathrm{a}}$ & $76.00 \pm 13.00^{\mathrm{b}}$ & $79.35 \pm 2.08^{\mathrm{b}}$ & $81.33 \pm 6.81^{\mathrm{b}}$ \\
\hline 3.86 & $48.00 \pm 5.57^{\mathrm{a}}$ & $67.52 \pm 2.08^{\mathrm{d}}$ & $58.33 \pm 2.08^{\mathrm{b}}$ & $80.00 \pm 6.08^{\mathrm{c}}$ \\
\hline 4.42 & $50.00 \pm 6.08^{\mathrm{a}}$ & $88.00 \pm 4.58^{\mathrm{b}}$ & $51.67 \pm 5.50^{\mathrm{a}}$ & $98.5 \pm 6.66^{\mathrm{b}}$ \\
\hline 4.97 & $62.67 \pm 2.52^{\mathrm{a}}$ & $89.00 \pm 3.00^{\mathrm{b}}$ & $84.33 \pm 7.23^{\mathrm{b}}$ & $81.67 \pm 6.35^{\mathrm{b}}$ \\
\hline
\end{tabular}

Means with the same superscript across the row are not significantly different ( $p \geq 0.05$ ). (Mean values $\pm S E$ )

The effects of acute concentrations of Paraquat with time on Oreochromis niloticus opercular ventilation count is presented in Table 3. At $0.00 \mathrm{mg} / 1,27.60 \mathrm{mg} / \mathrm{L}, 33.12 \mathrm{mg} / \mathrm{L}, 38.64 \mathrm{mg} / \mathrm{L}$, $44.16 \mathrm{mg} / \mathrm{L}$ and $49.64 \mathrm{mg} / \mathrm{L}$ concentration the opercular ventilation index were $29.00 \pm 0.00$, $32.67 \pm 1.53, \quad 34.67 \pm 4.51,43.33 \pm 3.05,47.67 \pm 3.21$ and $52.00 \pm 2.00$ respectively for 24 hours treatments; $32.33 \pm 2.09,62.33 \pm 5.51,75.00 \pm 6.93,38.67 \pm 1.53,56.67 \pm 2.08$ and $55.33 \pm 5.69$ respectively for 72 hours treatments; and $35.00 \pm 1.00,42.33 \pm 3.05,79.33 \pm 4.94,56.67 \pm 2.08,43.00 \pm 4.00$ and 
$50.00 \pm 1.73$ respectively for 96 hours treatments. Statistically, there was significant variation $(\mathrm{p}<0.05)$ among the exposure period. Furthermore, the opercular ventilation count were lesser in the control group $(0.00 \mathrm{mg} / \mathrm{l})$ compared to other concentration groups. The increase in opercular ventilation rate may be associated to the sudden response by the fish due to the shock which is an indication of hyperventilation according to Babatunde and Oladimeji (2014).

Table3. Effects of Acute Concentrations of Paraquat with Time on Oreochromis niloticus opercular ventilation count.

\begin{tabular}{|l|l|l|l|l|}
\hline \multicolumn{5}{|c|}{ Exposure time } \\
\hline Conc(mg/l) & \multicolumn{1}{|c|}{$24 \mathrm{hrs}$} & $48 \mathrm{hrs}$ & $72 \mathrm{hrs}$ & $96 \mathrm{hrs}$ \\
\hline 0 & $29.00 \pm 0.00^{\mathrm{a}}$ & $31.33 \pm 0.58^{\mathrm{b}}$ & $32.33 \pm 2.09^{\mathrm{b}}$ & $35.00 \pm 1.00^{\mathrm{c}}$ \\
\hline 2.76 & $32.67 \pm 1.53^{\mathrm{a}}$ & $63.67 \pm 3.51^{\mathrm{c}}$ & $62.33 \pm 5.51^{\mathrm{c}}$ & $42.33 \pm 3.05^{\mathrm{b}}$ \\
\hline 3.31 & $34.67 \pm 4.51^{\mathrm{a}}$ & $79.67 \pm 9.61^{\mathrm{b}}$ & $75.00 \pm 6.93^{\mathrm{b}}$ & $79.33 \pm 4.94^{\mathrm{b}}$ \\
\hline 3.86 & $43.33 \pm 3.05^{\mathrm{a}}$ & $84.67 \pm 5.89^{\mathrm{c}}$ & $38.67 \pm 1.53^{\mathrm{a}}$ & $56.67 \pm 2.08^{\mathrm{b}}$ \\
\hline 4.42 & $47.67 \pm 3.21^{\mathrm{a}}$ & $90.67 \pm 3.21^{\mathrm{c}}$ & $56.67 \pm 2.08^{\mathrm{b}}$ & $43.00 \pm 4.00^{\mathrm{a}}$ \\
\hline 4.97 & $52.00 \pm 2.00^{\mathrm{a}}$ & $89.00 \pm 3.00^{\mathrm{b}}$ & $55.33 \pm 5.69^{\mathrm{a}}$ & $50.00 \pm 1.73^{\mathrm{a}}$ \\
\hline
\end{tabular}

Means with the same superscript across the row are not significantly different ( $p \geq 0.05)$. (Mean values $\pm S E$ )

The effect of acute concentration of paraquat on Oreochromis niloticus on tail fin movement is presented in Table 4. At $0.00 \mathrm{mg} / \mathrm{l}, 27.60 \mathrm{mg} / \mathrm{L}, 33.12 \mathrm{mg} / \mathrm{L}, 38.64 \mathrm{mg} / \mathrm{L}, 44.16 \mathrm{mg} / \mathrm{L}$ and $49.64 \mathrm{mg} / \mathrm{L}$ concentration the tail fin movement were $30.00 \pm 6.08,52.33 \pm 5.51,65.00 \pm 5.29,66.67 \pm 10.11$, $66.00 \pm 1.00$ and $64.00 \pm 3.61$ respectively ( 24 hours), $47.00 \pm 1.00,52.67 \pm 6.66,97.67 \pm 1.53,63.00 \pm 7.81$, $67.00 \pm 1.00$ and $65.67 \pm 2.08$ respectively (48 hours), $22.0 \pm 1.00,44.61 \pm 10.50,85.33 \pm 5.51$, $76.33 \pm 1.53,68.00 \pm 1.73$ and $74.00 \pm 2.00$ respectively ( 96 hours). There was significant variation $(\mathrm{p}<0.05)$ among the exposure period. Furthermore, the opercular ventilation count were lesser in the control group $(0.00 \mathrm{mg} / \mathrm{l})$ compared to other concentration groups. The results also showed that the tail fin movement of the exposed fish to the toxicant at 24hours and 72 hours were higher compare to the 96 hours for the control group. Adeogun (2012) opined that an increase in tail movement is due to quest to escape from the toxicant and in the processes causing restlessness. Typically the fluctuations in the tail fin movement, opercular ventilation and air gulping index could be due to survival/ adaptation strategy by the fishes when they were exposure to the toxicants (Chindah et al., 2004).

Table4. Effect of acute concentration of paraquat on Oreochromis niloticus on tail fin movement

\begin{tabular}{|l|l|l|l|l|}
\hline \multicolumn{5}{|c|}{ EXPOSURE TIME } \\
\hline Conc $(\mathrm{mg} / \mathrm{l})$ & \multicolumn{1}{|c|}{$24 \mathrm{hrs}$} & $48 \mathrm{hrs}$ & $72 \mathrm{hrs}$ & $96 \mathrm{hrs}$ \\
\hline 0 & $30.00 \pm 6.08^{\mathrm{b}}$ & $47.00 \pm 1.00^{\mathrm{c}}$ & $32.67 \pm 0.58^{\mathrm{b}}$ & $22.0 \pm 1.00^{\mathrm{a}}$ \\
\hline 2.76 & $52.33 \pm 5.51^{\mathrm{a}}$ & $52.67 \pm 6.66^{\mathrm{a}}$ & $59.33 \pm 7.37^{\mathrm{a}}$ & $44.61 \pm 10.50^{\mathrm{a}}$ \\
\hline 3.31 & $65.00 \pm 5.29^{\mathrm{b}}$ & $97.67 \pm 1.53^{\mathrm{d}}$ & $53.67 \pm 4.04^{\mathrm{a}}$ & $85.33 \pm 5.51^{\mathrm{c}}$ \\
\hline 3.86 & $66.67 \pm 10.11^{\mathrm{ab}}$ & $63.00 \pm 7.81^{\mathrm{a}}$ & $70.00 \pm 0.00^{\mathrm{ab}}$ & $76.33 \pm 1.53^{\mathrm{b}}$ \\
\hline 4.42 & $66.00 \pm 1.00^{\mathrm{a}}$ & $67.00 \pm 1.00^{\mathrm{a}}$ & $66.00 \pm 1.00^{\mathrm{a}}$ & $68.00 \pm 1.73^{\mathrm{a}}$ \\
\hline 4.97 & $64.00 \pm 3.61^{\mathrm{a}}$ & $65.67 \pm 2.08^{\mathrm{a}}$ & $74.67 \pm 0.00^{\mathrm{b}}$ & $74.00 \pm 2.00^{\mathrm{a}}$ \\
\hline
\end{tabular}

Means with the same superscript across the row are not significantly different ( $p \geq 0.05)$. (Mean values $\pm S E$ )

The mortality rates and probit value of Oreochromis niloticus fingerlings exposed to acute concentration of paraquat dichloride is presented in Table 5. Fish mortality was observed in all the tanks except in the control tanks. At 96 hours the mortality rate at $27.60 \mathrm{mg} / \mathrm{L}, 33.12 \mathrm{mg} / \mathrm{L}, 38.64 \mathrm{mg} / \mathrm{L}$, $44.16 \mathrm{mg} / \mathrm{L}$ and $49.64 \mathrm{mg} / \mathrm{L}$ of paraquat dichloride were $30.56 \%, 36.11 \%, 55.56 \%, 61.11 \%$ and 63.89 $\%$ respectively. The probit chart from where the $\mathrm{LC}_{50}$ values was derived from substitution of the probit value of 50 in the equation in the chart and then taken the anti-logarithm value is presented in Figure 1. The result of the acute toxicity showed that paraquat was toxic to Oreochromis niloticus with $\mathrm{LC}_{50}$ value of $40.7684 \mathrm{mg} / \mathrm{l}$.

Table4.5. mortality rate and log of concentration in Oreochromis niloticus exposed to paraquat

\begin{tabular}{|l|l|l|l|l|l|}
\hline $\begin{array}{l}\text { Concentration of } \\
\text { paraquat in }(\mathrm{mg} / \mathrm{l})\end{array}$ & $\begin{array}{l}\text { Log of } \\
\text { concentration }\end{array}$ & $\begin{array}{l}\text { Number of fish } \\
\text { exposed }\end{array}$ & $\begin{array}{l}\text { Number of } \\
\text { mortality }\end{array}$ & \%mortality & Probit value \\
\hline 0.00 & 0.000 & 36 & 0 & 0 & 0.00 \\
\hline 2.76 & 0.441 & 36 & 11 & 30.56 & 4.00 \\
\hline 3.31 & 0.510 & 36 & 13 & 36.11 & 4.64 \\
\hline 3.86 & 0.587 & 36 & 20 & 55.56 & 5.15 \\
\hline 4.42 & 0.645 & 36 & 22 & 61.11 & 5.28 \\
\hline 4.97 & 0.696 & 36 & 23 & 63.89 & 5.36 \\
\hline
\end{tabular}




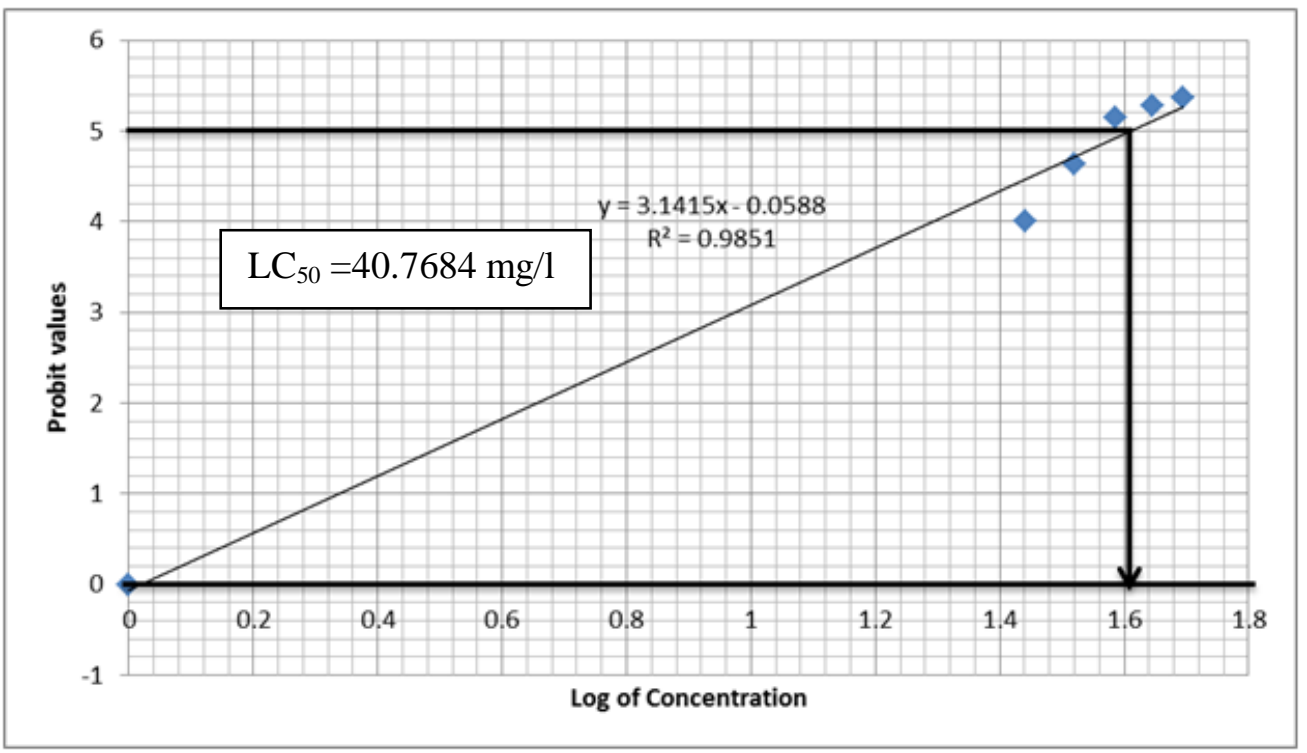

Figure1. Probit value against log concentration of the toxicant

The $\mathrm{LC}_{50}$ values reported in this study is higher than the value of $30.28 \mathrm{ppm}, 22.72 \mathrm{ppm}, 20.23 \mathrm{ppm}$ and $18.44 \mathrm{ppm}$ reported in 48 hours, 72 hours and 96 hours in fingerlings of Heterobranchus bidosalis exposed to paraquat dichloride as reported by Aghoghovwia and Izah (2018a), 28.13, 27.61, 26.22 and $25.71 \mathrm{mg} / \mathrm{l}$ at for 24, 48, 72 and 96 hours respectively in fingerlings of Labeo rohita exposed to paraquat as reported by Arivu et al. (2016), $7.16 \mathrm{mg} / \mathrm{l}, 4.45 \mathrm{mg} / \mathrm{l}, 2.19 \mathrm{mg} / \mathrm{l}$ and $1.41 \mathrm{mg} / \mathrm{l}$ for 24 hours, 48 hours, 72 hours and 96 hours in adult Trichogastertrichopterus exposed to paraquat as reported by Banaee et al. (2013), $1.75 \mathrm{mg} / \mathrm{l}$ after 96 hours of exposing juvenile Clarias gariepinus to Paraquat dichloride as reported by Ladipo (2011). Babatunde and Oladimeji (2014) reported $\mathrm{LC}_{50}$ value of $12.25 \mathrm{mg} / \mathrm{l}$ in Oreochromis niloticus fingerlings exposed to paraquat. The variation could be due to size of the fish species (age), length and weight, and biochemical characteristics (Aghoghovwia and Izah, 2018a).

\section{CONCLUSION}

It was observed in this study that behavioural characteristics which include opercular ventilation count, tail fin movement rate and air gulping index were adversely affected by the toxicant used in this experiment. $\mathrm{LC}_{50}$ value of $40.7684 \mathrm{mg} / \mathrm{L}$ was also found to be the acute toxicity of paraquat dichloride to Oreochromis niloticus fingerlings. This indicates high mortality threshold. It is therefore concluded that this toxicity, if not checked could lead to behavioural abnormalities as well as death in fish. Hence the usage must be monitored and controlled especially when in use close to any aquatic ecosystem.

\section{REFERENCES}

Adeogun, A.O., 2012. Acute toxicity of methanolic extract of Raphia hookeri on life stages of Clarias gariepinus. Journal of Science Research, 11(1): 179-186.

Agedah, E.C., Ineyougha, E.R., Izah, S.C., and Orutugu, L.A., 2015. Enumeration of total heterotrophic bacteria and some physico-chemical characteristics of surface water used for drinking sources in Wilberforce Island, Nigeria. Journal of Environmental Treatment Techniques. 3(1): 28 - 34.

Aghoghovwia, O.A., Umoru O.D., and Izah S.C., 2018a., Physicochemical characteristics of nun river at Gbarantoru and Tombia Axis in Bayelsa State, Nigeria, Bioscience Methods, 9(1): 1-11

Aghoghovwia, O.A., Miri, F.A. and Izah, S.C., 2018b.Impacts of Anthropogenic Activities on Heavy Metal Levels in Surface Water of Nun River around Gbarantoru and Tombia Towns, Bayelsa State, Nigeria. Annals of Ecology and Environmental Science, 2(2): 1 - 8.

Aghoghovwia, O.A., Izah S.C., and Miri F.A., 2018c. Environmental risk assessment of heavy metals in sediment of Nun River around Gbarantoru and Tombia Towns, Bayelsa State, Nigeria, Biological Evidence, 8(3): 21-31 (doi: 10.5376/be.2018.08.0003)

Aghoghovwia, O.A., and Izah, S.C., 2018a.Acute toxicity of Paraquat dichloride based herbicide against Heterobranchus bidorsalis fingerlings. EC Agriculture, 4(2): 128-132. 
Aghoghovwia, O.A., and Izah, S.C., 2018b. Toxicity of glyphosate based herbicides to fingerlings of Heterobranchus bidorsalis. International Journal of Avian \& Wildlife Biology, 3(5):397-400.

Akinsorotan, A.M., 2015. Histological Studies off African Catfish (Clarias gariepinus) Exposed To Varying Concentrations Of Dizensate (Glyphosate: N-phosphonomethyl glycine). Ph.D Thesis.Delta State University, Abraka-Nigeria. 132p

Arivu, I., Muthulingam, M., and Jiyavudeen, M., 2016.Toxicity of paraquat on freshwater fingerlings of Labeo rohita (Hamilton). International Journal of Scientific \& Engineering Research, 7(10): 1965 - 1971.

Babatunde, M.M., and Oladimeji A.A., 2014. Comparative study of Acute toxicity of Paraquat and Galex to Oreochromis niloticus. International Journal of Advanced Scientific and Technical Research, 3(4), 437 444

Banaee, M., Davoodi M.H., and Zoheiri F. 2013. Histopathological changes induced by paraquat on some tissues of gourami fish (Trichogastertrichopterus). Open Vet J. 2013; 3(1): 36-42.

Ben-Eledo V.N., Kigigha L.T., Izah SC, Eledo B.O., 2017a.Water quality assessment of Epie creek in Yenagoa metropolis, Bayelsa state, Nigeria. Archives of Current Research International, 8(2): $1-24$

Ben-Eledo, V.N., Kigigha, L.T., Izah, S.C., and Eledo B.O., 2017b.Bacteriological Quality Assessment of Epie Creek, Niger Delta Region of Nigeria.International Journal of Ecotoxicology and Ecobiology. 2(3): 102108

Bhatnagar, A., and Devi, P., 2013. Water quality guidelines for the management of pond fish culture. International Journal of Environmental Sciences, 3(6), 1980 - 2009.

Boyd, C. E., 1979. Water quality in warmwater fish ponds. Auburn University Agricultural Experiment Station, Auburn, Alabama, USA.

Chindah, A.C., Sikoki, F.D., and Vincent-Akpu, I., 2004.Toxicity of organophosphate pesticide (chloropyrifos) on common Niger Delta wetland fish- Tilapia guineensis (Bleck 1862).Journal of Applied Science and Environmental Management, 8(2):11-17.

Finney, D.J., 1971. Probit Analysis. Cambridge University Press, London, United Kingdom, p 123-125.

Inyang, I.R., Ayogoi, T.A., and Izah, S.C., 2018. Effect of lindane on some selected electrolytes and metabolites of Clarias gariepinus (juveniles). Advances in Plants and Agricultural Research, 8(5):394-397.

Inyang, I.R., Ajimmy, R., and Izah, S.C., 2017a.Organosomatic index and behavioral response of Heterobranchus bidorsalis exposed to rhonasate 360sl containing glyphosate (isopropylamine salt glycine). ASIO J Microbiol Food Sci Biotechnol Innov3(1): 6 - 14.

Inyang, I.R., Izah S.C., Johnson, D.T., Ejomarie, O.A., 2017b.Effects of Lambda cyhalothrin on some electrolytes and metabolites in organs of Parpohiocephalusobscurus. Biotechnol Res 3(1): 6-10.

Inyang, I.R., Ollor, A.O., and Izah, S.C., 2017c. Effect of Diazinon on Organosomatic Indices and Behavioural Responses of Clarias gariepinus (a Common Niger Delta Wetland Fish). Greener J BiolSci 7(2): 15 - 19.

Inyang, I.R., Seiyaboh, E.I., and Job, U.B., 2017d. Condition Factor, Organosomatic Indices and behavioural Abnormalities of Clarias gariepinus exposed to Lambda Cyhalothrin. Greener J Life Sci4 (1): 001-005.

Inyang, I.R., Akio, K., and Izah, S.C., 2016a.Effect of dimethoate on lactate dehydrogenase, creatinine kinase and amylase in Clarias lazera. Biotechnol Res 2(4): 155- 160.

Inyang, I.R., Kenobi, A, and Izah S.C., 2016b. Effect of dimethoate on some selected metabolites in the brain, liver and muscle of Clarias lazera. Sky J Biochem Res 5(4): 63-68

Inyang, I.R., Obidiozo, O.Z., and Izah, S.C., 2016c.Effects of Lambda cyhalothrin on protein and Albumin content in the kidney and liver of Parpohiocephalus obscurus. EC Pharmacol Toxicol 2(3): 148-153.

Inyang, I.R., Okon N.C., and Izah S.C., 2016d. Effect of glyphosate on some enzymes and electrolytes in Heterobranchus bidorsalis (a common African catfish).Biotechnol Res2(4):161-165

Inyang, I.R., Thomas, S., and Izah, S.C., 2016e. Activities of electrolytes in kidney and liver of Clarias gariepinus exposed to fluazifop-p-butyl. J Biotechnol Res 2(9): 68 - 72.

Inyang, I.R., Thomas, S., and Izah, SC., 2016f.Evaluation of Activities of Transferases and Phosphatase in Plasma and Organs of Clarias gariepinus Exposed to Fluazifop-p-Butyl. J Environ Treat Techniq 4(3): 9497.

Izah, S.C., and Ineyougha, E.R., 2015. A review of the microbial quality of potable water sources in Nigeria. J AdvBiol Basic Res 1(1): 12 - 19.

Izah, S.C., and Srivastav, A.L., 2015. Level of arsenic in potable water sources in Nigeria and their potential health impacts: A review. J Environ Treat Techniq 3(1): 15 - 24.

Izah, S.C., Chakrabarty, N., and Srivastav, A.L., 2016.A Review on Heavy Metal Concentration in Potable Water Sources in Nigeria: Human Health Effects and Mitigating Measures. Exposure and Health, 8:285304. 
Ladipo, M.K., 2011. Acute Toxicity, Behavioural Changes and Histopathological Effect of Paraquat Dichloride on Tissues of Catfish (Clarias gariepinus). International Journal of Biology,3(2), 67 - 74.

Nwani, C.D., Ekwueme, H.I., Ejere, V.C., Onyeke, C.C., Chukwuka, C.O., Peace, O.S., andNwadinigwe, A.O., 2015. Physiological effects of paraquat in juvenile African catfish Clarias gariepinus (Burchel 1822): Nigerian Journal of Coastal Life Medicine. 3(1): 35-43.

Ogamba, E.N., Seiyaboh, E.I., Izah, S.C., Ogbugo, I., and Demedongha, F.K., 2015c. Water quality, phytochemistry and proximate constituents of Eichhorniacrassipes from Kolo creek, Niger Delta, Nigeria. International Journal of Applied Research and Technology, 4(9): 77 - 84.

Ogamba, E.N., Izah, S.C., and Oribu T., 2015a.Water quality and proximate analysis of Eichhornia crassipes from River Nun, Amassoma Axis, Nigeria. Research Journal of Phytomedicine. 1(1): 43 - 48.

Ogamba, E.N., Izah S.C., and Toikumo, B.P. 2015b.Water quality and levels of lead and mercury in Eichhornia crassipes from a tidal creek receiving abattoir effluent, in the Niger Delta, Nigeria.Continental Journal of Environmental Science. 9(1): 13 - 25.

Ogamba, E.N., Izah, S.C., and Nabebe G., 2015.Effects of 2, 4-Dichlorophenoxyacetic acid in the electrolytes of blood, liver and muscles of Clarias gariepinus. Nigerian Journal of Agriculture Food and Environment, 11(4): $23-27$.

Ojesanmi, A.S., Richard, G., and Izah, S.C. 2017. Mortality Rate of Clarias gariepinus Fingerlings Exposed to 2 , 3- dichlorovinyl dimethyl Phosphate. Journal of Applied Life Sciences International, 13(1): 1-6

Okechukwu, O.E., Usman, I.B., and Jehu, A., 2013. Investigation of acute toxicity of chlorpyrifos-ethyl on Clarias gariepinus - (Burchell, 1822) using some behavioural indices. International Journal of Basic and Applied Sciences, 2 (2): 176-183

Okomoda, V. T., and Ataguba, G. A., 2011. Blood glucose response of Clarias gariepinus exposed to acute concentrations of glyphosate-isopropylammonium (Sunsate®). Journal of Agricultural and Veterinary Sciences, 3(6), 69-75.

Oloruntuyi, O. O.,Mulero, O., and Odukale, B. 1993.The effects of two pesticides on Clariasgariepinus. In: 10th Annual Conference of the Fisheries Society of Nigeria (FISON), 16-20 November 1992, Abeokuta, Nigeria, pp 173-177. http://aquaticcommons.org/3508/1/173.pdf. Accessed June 28th, 2015.

Omoniyi, I.A., Agbon A.O., and Sodunke, S.A., 2002. Effects of lethal and sub-lethal concentrations of tobacco (Nicotiana tobaccum), leaf dust extract on weight and haematological changes in Clarias gariepinus (Buchell1822). Journal of Applied Science and Environmental. Management, 6: 37-41.

Oyoroko, E., and Ogamba EN., 2017a. Toxicity of Detergent Containing Linear Alkyl benzene Sulphonate on Some Commonly Cultured Fish Species in the Niger Delta. Journal of Environmental Treatment Techniques, 5(2): 72-77

Oyoroko, E., and Ogamba, E.N., 2017b.Effects of detergent containing linear alkyl benzene sulphonate on behavioural response of Heterobranchus bidorsalis, Clarias gariepinus and Heteroclarias. Biotechnological Research, 3(3):55-58

Seiyaboh, E.I., Izah, S.C. and Oweibi, S., 2017. Assessment of Water quality from Sagbama Creek, Niger Delta, Nigeria. Biotechnological Research, 3(1): 3(1):20-24

Seiyaboh, E.I., and Izah S.C., 2017a. Review of Impact of Anthropogenic Activities in Surface Water Resources in the Niger Delta region of Nigeria: A case of Bayelsa state. International Journal of Ecotoxicology and Ecobiology. 2(2): $61-73$.

Seiyaboh, E.I., and Izah, S.C., 2017b. Bacteriological assessment of a tidal creek receiving slaughterhouse wastes in Bayelsa state, Nigeria. Journal of Advances in Biology and Biotechnology, 14(1): 1 -7.

Citation: Ademola Michael Akinsorotan et al., " Acute Toxicity of Paraquat Dichloride on Fingerlings of Oreochromis niloticus", International Journal of Research Studies in Biosciences (IJRSB), vol. 7, no. 1, pp. 2936, 2019. http://dx.doi. org/10.20431/2349-0365.0701005

Copyright: (C) 2019 Authors. This is an open-access article distributed under the terms of the Creative Commons Attribution License, which permits unrestricted use, distribution, and reproduction in any medium, provided the original author and source are credited. 